\title{
The analysis of alien species in Mykolayiv urban flora by primary aerials and the time
}

\author{
Melnik Ruslana Petrivna
}

\begin{abstract}
MELNIK R. P. 2005: The analysis of alien species in mykolayiv urban flora by primary aerials and the time Chornomor. Botan. Journ., vol. 1, №2: 67-69.

The alien fraction of the Mykolayiv urban flora includes 235 species, which are composed $25.8 \%$ of the total species number of the studied flora. Geographic range 28 groups are combined in eight migroelements of the flora. They are: Mediterranean migroelement -48 species, Mediterranean Irano-Turanian - 42, North American - 37. Four species are of anthropogenic origin. Primary areas of distribution were not considered for five species. All alien species are distributed between three migrochronoelements by their period of immigration. They are archeophytes (immigrated before the $15^{\text {th }}$ century) -77 species, kenophytes (immigrated during the $16-19^{\text {th }}$ centuries) -69 , and eukenophytes (immigrated in the $20^{\text {th }}$ century) -89 .
\end{abstract}

Keywords: alien species, urban flora, migration analysis

Ключові слова: адвентивні види, урбанофлора, міграційний аналіз

\section{Introduction}

Anthropogenic impact on natural landscapes, namely, industrial forms of management serves as a powerful factor causing changes of plant cover the borders of cities and suburbs. The basic man-made transformation processes are bringing, spreading and naturalization of alien plants.

Alien group within Mykolayiv urban flora includes 235 species, which constitutes $25,8 \%$ of the whole flora studied here. In general, alien constitute $14,2 \%$ of the Ukraine flora [ПротоПОПОвА, 1973 ] and it confirms a considerable role of cities in the invasion of alien species.

\section{Materials and Methods}

This investigation includes 235 plant specimens collected in Mikolayiv during 19962003. All taxa are given according to S.L. Mosyakin and M.M. Fedoronchuk [MosYAKIN, FEDORONCHUK, 1999]. While carrying out the migration analysis of urban flora alien fraction in urban flora of Mykolayiv, we used the alien plants classification of Ya. Kornas [KORNAS, 1968] that is modified by V.V. Protopopova [ПротопоПовА, 1991] and enriched by I.I. Moysienko [МойсІєнКО, 1999]. This analysis includes two directions: place migration analysis (migroelement) and time migration analysis (migrochronoelement). According to Yu. D. Kleopov [КЛЕОПОВ, 1990] a migrochronoelement is a group of species migrated to a certain territory simultaneously.

\section{Results}

As the result of the analysis of alien element structure 28 area groups of primary natural habitats have been recognized (chart 1). The groups were singled out due to the similar classification by V.V. Protopopova [ПРОтоПОПОвА, 1973] and developed for the alien element of the Ukrainian flora.

To make the analysis more handy 28 natural habitat groups were unified into 8 flora elements according Moysienko [1999] (chart 1). The four species are found to be of anthropogenic origin (due to Zayonts A.). The primary natural habitats of 5 alien species have not been found.

(C) R.P. Melnik

Чорномор. ботан. журн., 2005, T. 1, № 2: 67-69. 
The structure of alien migroelements of flora studied (chart 1) shows a prevailing role of the species of the Old Mediterranean origin (alien migroelements: Mediterranean, Mediterranean-Irano-Turanian and Turan-Iranian) in the formation of its alien element. They constitute $56,6 \%$ of the general number of alien species in Mykolayiv urban flora.

Natural habitat groups of migroelements of Mykolayiv urban flora

Table 1.

Ареалогічні групи мігроелементів урбанофлори Миколаєва

\begin{tabular}{|c|c|c|}
\hline Type of migroelement & $\begin{array}{c}\text { Natural habitat group and } \\
\text { number of species }\end{array}$ & $\begin{array}{c}\text { Total number of } \\
\text { species }\end{array}$ \\
\hline Mediterranean & $\begin{array}{l}\text { Mediterranean }-48 \\
\text { East Mediterranean }-3 \\
\text { West Mediterranean }-1 \\
\text { Asia Minor }-1\end{array}$ & 53 \\
\hline $\begin{array}{l}\text { Mediterranean-Irano- } \\
\text { Turanian }\end{array}$ & $\begin{array}{l}\text { Mediterranean-Irano-Turanian }-42 \\
\text { Mediterranean-East-Turanian }-2 \\
\text { Mediterranean-Turanian }-3\end{array}$ & 47 \\
\hline North American & North American -37 & 37 \\
\hline Irano-Turanian & $\begin{array}{l}\text { Irano-Turanian }-19 \\
\text { Middle East }-10 \\
\text { Central Asian }-2 \\
\text { Caucasian }-2 \\
\text { Iranian }-1\end{array}$ & 33 \\
\hline Asian & $\begin{array}{l}\text { Asian }-10 \\
\text { East Asian }-5 \\
\text { South-East Asian }-5 \\
\text { South Asian }-1 \\
\text { South- and Southeast Asian }-1 \\
\text { Indo- Malayan - } 2 \\
\text { Indo- Malayan and Sudanese - } 1\end{array}$ & 25 \\
\hline European & $\begin{array}{l}\text { Middle European }-7 \\
\text { South European }-6 \\
\text { West European }-2 \\
\text { Balkan }-3\end{array}$ & 18 \\
\hline South American & $\begin{array}{l}\text { South American - } 10 \\
\text { Southern and Central American }-2\end{array}$ & 12 \\
\hline African & African -1 & 1 \\
\hline \multicolumn{3}{|c|}{$\begin{array}{ll}\text { Antropogenic origin } & 4 \\
\end{array}$} \\
\hline Unknown origin & 5 & \\
\hline
\end{tabular}

Data highlited are agreement with the other Black Sea regions such as Odessa [ВАСИЛЬЕВА-НЕМЕРЦАЛОВА, 1996], Kherson [МОЙСІєНКО, 1999] as well as with the synanthropic flora of Ukraine in general [ПРОтОПОПОВА, 1973]. Mediterranean migroelement an analogous prevails here (53 species or $22,5 \%$ of the general number of the adventitious urban flora), especially Consolida ajacis (L.) Schur, Diplotaxis tenuifolia (L.) DC., Lamium purpureum L., Onopordum acanthium L., Saponaria officinalis L., Sisymbrium loeselii L. etc.

There are 42 Mediterranean-Irano-Turanian species (Anisantha sterilis (L.) Nevski, Atriplex prostrata Boucher, Bromus squarrosus L., Lactuca serriola Torner, Lamium amplexicaule L., Papaver dubium L.) in the Mediterranean-Irano-Turanian migroelement (17,9\% of total amount). The third largest group of species is the North American 
migroelement (37 species or 15,7\%), including Acer negundo L., Amaranthus albus L., A. blitoides S. Wats., Cenchrus longispinus (Hack.) Fernald, Oenothera biennis L., Oxybaphus nyctagineus (Michx.) Sweet etc. The smallest group is the African migroelement - only one species.

While carrying out the migration analysis of alien species in terms of time spreading, we used the following migroelement classification [MOYSIENKO, 1999]:

1. Archaeomigrochronoelemnt;

2. Kenomigrochronoelement;

3. Eukenomigrochronoelement.

The classification of the Ukrainian alien plants in terms of time spreading of archaeophytes and kenophytes by V.V. Protopopova [ПРОтОПОПОВА, 1991] served as a basis for such a developed division. The eukenophytes were classified directly using literature data and herbarium collections being dated: by the end of the 19-th - beginning of the 20-th century and relating the researched area. The most intensive alien species invasion process has been developing in the $20^{\text {th }}$ century that was proved by a prevailing number of appropriate species within the alien migroelements (chart 1), eukenomigrochronoelements ( 89 species or $38,0 \%)$.

The archaeomigrochronoelemnts and kenomigrochronoelements include approximately equal number of species: 77 (32,7\%), and 69 (29,3\%) correspondingly.

The fate of new alien species differed. Some of them disappeared quickly and other adapted to a new environment with further wide distribution. Many of eukenophytes, i.e. alien species that was brought to a studied area in the 20-th century, did not propagate widely on the territorywith showing low naturalization level. 23 eukenophytes reached the expansion level in the urban flora of Mykolayiv, in particular: Acer negundo, Ailanthus altissima (Mill.) Swingle, Ambrosia artemisifolia L., Amorpha fruticosa L., Artemisia annua L., Atriplex hortensis L., Bidens frondosa L., Cenchrus longispinus, Chenopodium striatiforme J. Murr, Cuscuta campestris Yunck., Iva xantifolia Nutt., Diplotaxis muralis (L.) DC., D. tenuifolia, Echinocystis lobata (Michx.) Torr. \& A. Gray, Galinsoga parviflora Cav., Grindelia squarrosa (Pursh) Dunal, Kochia scoparia (L.) Schrad., Medicago sativa L., Saponaria officinalis, Ulmus pumila L., Xanthium albinum (Widder) H. Scholz, X. pensilvanicum Wallr. and Xanthoxalis dillenii (Jacq.) Holub. They are present in all types of anthropogenic flora complexes.

\section{Literature}

ВАСИЛЬЕВА-НЕМЕРцАЛОВА Т.В. Синантропна флора припортових міст північно-західного Причорномор`я і шляхи ії розвитку: Автореф. дис. ... канд. біол. наук: 03.00.05. - К., 1996. - 22 с.

КЛЕОПОв Ю.Д. Анализ флоры широколиственных лесов Европейской части СССР. - К.: Наук. думка, 1990. - $352 \mathrm{c}$.

Мойсієнко I.I. Урбанофлора Херсона: Дис... канд. біол. наук: 03.00.05. - Ялта, 1999. - 19 с.

ПротопоПОвА В.В. Адвентивні рослини Лісостепу і Степу України. - К.: Наук. думка, 1973. - 192 с.

ПротопоповА В.В. Синантропная флора Украины и пути ее развития. - К.: Наук. думка, 1991. - 204 с.

MosyaKin S., FEDORONCHUK M., Vascular plants of Ukraine: a nomenclatural checklist. - Kiev, 1999. - 345 p.

KORNAS J. Geographical - Historical Classification of Synantropic Plants // Mater. Zakl. Fitosoc. Stos. UW. 1968. - № 25. - P. 33-41.

Рекомендує до друку

Отримано 26.08.2005 p.

А.В. Сна

Adpeca aвmopa:

Р.П. Мельник

Херсонський державний університет

вул. 40 років Жовтня, 27

Херсон, 73000

Україна
Author's address:

R.P. Melnik

Kherson State University

40-let Oktjabrja St., 27

Kherson, 73000

Ukraine 